me of your return home, has prevented me writing to you sooner, to state the grounds on which I promised to give one hundred ponnds to the Benevolent Fund of the Provincial Medical Association. My wish and object in this act is to encourage the establishment of a permanent fund for the relief of our necessitous professional brethren, and, in as many cases as possible, also those who must inevitably be participators in their distreas and porerty. I therefore determined to make it a sine qua non principle, that this sum should be invested in some approved security, and that the interest should alone be applied to the uses of this Society ; and $I$ also further wish it to be understood, that if at any time unforseen causes occur which will destroy the existence of our Association, (a result which I earnestly hope will never happen,) this amount is returned to me,in order that I may again apply it to some other benevolent purpose.

My subscription has been ten shillings per annum but I wish to increase it to twenty shillings.

If you will be so good as to inform me tbrough what channel I must send you the amount I shall feel much obliged.

Yours, most respectfully, THOMAS RADFORD.

To Dr. Conolly, near Cheltenham,

Treasurer, \&c., of the Benevolent Fund of the

Provincial Medical and Surgical Asssociation.

\section{PREMATURE INTERMENT.}

It is stated that the cases of premature interment in France, prevented by fortuitous circumstances, amount, since the year 1833 , to 94 . Of these, 35 persons awoke of themselves from their lethargy at the moment the funeral ceremony was about to commence; 13 recovered in consequence of the affectionate care of their families; 7 in consequence of the fall of the coffins in which they were inclosed; 9 owed their recovery to wounds inflicted by the needle in sewing their winding sheet; 5 to the sensation of suffocation they experienced in their coffin; 19 to their interment having been delayed by fortuitoás circumstances; and 6 to their interment having been delayed in consequence of doubts having been entertained of their death.

\section{PROVINCIAL MEDICAL AND SURGICAL ASSOCIATION. \\ VOLUME OT TRAN8ACTION8.}

The members of the Provincial Medical and Surgical Association are respectfully informed that the fourteenth volume of the Transactions of the Association is now nearly ready, and will shortly be issued. Those gentlemen who have not paid up their subscriptions for the last year, are requested to forward them, either to the Treasurer of the Association, Dr. Hastings, or to the Secretary, as the volume cannot be supplied to members whose subscriptions are in arrear.

ROBERT J. N. STREE'TEN,

Secrotary.

\section{SOCIETY OF APOTHECARIES.}

Gentlemen admitted Licentiates, Thursday, January 22nd :-Thomas Benjamin Home, Basingstoke; Thos. Brooks Bumpstead, Langford; Richard Penrose Bell, Yorkshire; Samuel Gibbon, Kettering, Northamptonhsire.

\section{OBITUARY.}

Died on the 11th instant, aged 56, Edwin Harrison M.D., Physician to the Marylebone Infirmary.

We regret also to announce the death of $\mathrm{Dr}$. Alexander John Hannay, of Glasgon, "an event which," to borrow the words of a respected contemporary, " has shed a deep gloom throughout the wide professional circle in which he moved, and among the numerous friends and well-wishers whom the many excellencies of his character had drawn around him."

\section{ERRATA.}

In the last number, at page $44, \mathrm{col} .1$, line 31 , for "Prigean," read Prujean; line 32, for "Maydon," read Mayerne.

\section{TO CORRESPONDENTS.}

Communications have been received from Dr. J. C. Badeley ; Mr. J. E. Wood ; W. A. G. ;Mr. C. R. Bree ; Dr. Cotton ; Dr. Fife

The Militia.-A Correspondent, who is a member of the London College of Surgeons, and a Licentiate of the Society of Apothecaries, is informed that Medical Practitioners are not named in the Militia Acts among those who are exempted from service.

It is doubtful whether members of the London Colleges of Physicians and Surgeons are exempt. As the question is one of considerable interest to the profession, we quote the following observations given by one of our Contemporaries on the subject:- " $\mathrm{By}$ the statute 32, Henry VIII., c. 40, physicians are however exempted from watch and ward; and though the question has never yet been decided, it seems extremely probable that the exemption extends to militia service, in the case of all physicians residing in London and its suburbs, and belonging to the college either as Fellows or Licentiates. By the statute 32 Henry VIII., cap. 42, all the members of the College of Surgeons are exempted from 'bearing of armour,' or being put to any 'watches or inquests,' and the only question is whether this exception does not extend both to service persopally and by a substitute. This, however, is another legal point undecided. Apothecaries have no exemption of any kind, either by their own Act of 1815 , or by the Militia Acts."-Medical Times.

It is requested that all letters and communications be sent to Dr. Streeten, Foregate Street, Worcester. Parcels, and books for review, may be addressed to the Editor of the Provincial Medical and Surgical. Journal, care of Mr. Churchill, Princess Street, Soho. 